\title{
RANCANG BANGUN SISTEM BASIS DATA DESA WISATA UNTUK DAERAH ISTIMEWA YOGYAKARTA
}

\author{
Yonathan Dri Handarkha $^{1}$, F. Anita Herawati ${ }^{2}$, Anna Purwaningsih ${ }^{3}$ \\ ${ }^{1}$ Fakultas Teknologi Industri, Program Studi Teknik Informatika \\ Universitas Atma Jaya Yogyakarta \\ ${ }^{2}$ Fakultas Ilmu Sosial dan Ilmu Politik, Program Studi Ilmu Komunikasi, \\ Universitas Atma Jaya Yogyakarta \\ ${ }^{3}$ Fakultas Ekonomi, Program Studi Akuntansi, Universitas Atma Jaya Yogyakarta \\ 1'yonathan_dh@staff.uajy.ac.id, ${ }^{2}$ anita_hera@yahoo.com, ${ }^{3}$ annapurwaningsih1977@gmail.com
}

\begin{abstract}
Abstrak
Desa wisata merupakan salah satu bentuk upaya pemberdayaan masyarakat desa yang berdampak pada peningkatan kesejahteraan masyarakat dengan menciptakan lapangan kerja baru dan sumber pendapatan. Di Daerah Istimewa Yogyakarta mulai bermunculan desa wisata baru, tetapi tidak semua dapat berjalan dan berkembang. Selain dikarenakan pengelolaan yang kurang profesional, banyak desa wisata yang tidak memiliki kemampuan sumber daya manusia yang baik dan kompeten untuk mempromosikan dan memasarkan desanya kepada calon wisatawan yang biasanya berasal dari luar daerah bahkan wisatawan asing. Melalui pemanfaatan teknologi informasi dan komunikasi, permasalahan di atas bisa teratasi. Dengan tersedianya sebuah website sebagai sumber basis data desa wisata yang bisa diakses melalui internet, informasi mengenai seluruh potensi yang terdapat desa wisata di Yogyakarta lengkap dengan fasilitas, keunikan dan kelebihan bisa tersampaikan kepada calon wisatawan dengan cara yang mudah dan efisien. Selain itu, sistem tersebut juga dapat digunakan sebagai dasar untuk membantu pihak masyarakat desa wisata dan pengelola untuk mengambil keputusan. Dari sisi pemerintah sistem ini dapat digunakan untuk memonitor desa wisata melalui indikator yang diberikan baik untuk kepentingan administrasi maupun pengembangan. Penelitian ini bertujuan untuk merancang dan membangun sebuah sistem informasi berbasis web untuk mendapatkan basis data desa wisata di daerah DIY. Sistem yang dibangun dibuat dalam bentuk prototype model yang selanjutnya diimplementasikan untuk membangun sebuah basis data guna pengelolaan dan pengembangan desa wisata.
\end{abstract}

Kata kunci: desa wisata, website, basis data, promosi

\section{PENDAHULUAN}

Teknologi informasi dan komunikasi (TIK) saat ini telah menjadi salah satu faktor penting dalam mendukung dan mempromosikan potensi wisata dari suatu daerah. Tanpa adanya sebuah strategi promosi yang baik, sebuah objek wisata yang sangat berpotensi sekalipun akan sulit berkembang dikarenakan sepinya pengunjung. Padahal yang menjadi salah satu tolak ukur sebuah objek wisata dikatakan mengalami kemajuan, bisa ditinjau dari jumlah wisatawan yang mengunjungi objek wisata tersebut. Dengan mengintegrasikan TIK sebagai bagian dari strategi promosi, sebuah objek wisata akan memiliki keunggulan dan kelebihan yang bisa menarik banyak wisatawan untuk datang. Hal tersebut dikarenakan TIK memungkinkan setiap calon wisatawan bisa memperoleh informasi yang dibutuhkan mengenai objek wisata dari mana saja dan kapan saja dengan cepat dan mudah [1]. Melalui keunggulan tersebut, peningkatan ketergantungan industri pariwisata terhadap pemanfaatan TIK telah menjadi salah satu tantangan utama yang dihadapi oleh pelaku pariwisata di negara negara berkembang [2].

Desa wisata adalah salah satu objek wisata yang merupakan bentuk dari upaya pemberdayaan masyarakat desa yang berdampak pada peningkatan kesejahteraan dengan menciptakan lapangan kerja baru dan sumber pendapatan. Desa-desa wisata baru di Daerah Istimewa Yogyakarta (DIY) banyak bermunculan pada sekitar tahun 2006, tetapi tidak semua dapat berjalan dan bertahan. Saat itu terdapat sekitar 80-an desa wisata di Yogyakarta. Dalam kurun waktu tujuh tahun dari jumlah awal tersebut, tersisa kurang lebih 40 desa wisata dan beberapa diantaranya mengalami kevakuman. Terdapat beberapa hal yang menyebabkan desa wisata tersebut menjadi tidak berkembang. Selain dikarenakan pengelolaan yang kurang profesional, banyak desa wisata yang tidak memiliki kemampuan sumber daya manusia yang baik dan kompeten untuk mempromosikan dan memasarkan desanya kepada calon calon wisatawan yang biasanya berasal dari luar daerah bahkan wisatawan asing. Sebaliknya desa wisata yang berkembang adalah desa wisata 
yang mendapatkan dukungan dari banyak pihak terutama dari masyarakat desa itu sendiri dan dikelola dengan baik salah satunya pada sektor promosi dan pemasaran.

Permasalahan di atas sebenarnya dapat diatasi apabila setiap desa wisata memiliki sebuah sistem yang mampu menyajikan informasi mengenai potensi dari desa wisata dan sarana pendukungnya kepada calon wisatawan. Penggunaan TIK sebagai sarana promosi menjadi sangat penting dikarenakan rata rata calon wisatawan dari sebuah desa wisata berasal dari luar daerah. Pemanfaatan teknologi informasi seperti internet mampu menyediakan sebuah solusi untuk membantu sebuah objek wisata untuk terus bertahan dari waktu ke waktu melalui pemasaran dan promosi potensi wisata secara online kepada calon wisatawan [3]. Dengan tersedianya sebuah situs sebagai sumber basis data desa wisata yang bisa diakses melalui internet, informasi mengenai seluruh potensi yang terdapat desa wisata di Yogyakarta lengkap dengan fasilitas, keunikan dan kelebihan bisa tersampaikan kepada calon wisatawan dengan cara yang mudah dan efisien. Dengan memanfaatkan jaringan internet global yang semakin murah dan bisa di akses oleh siapa saja, informasi mengenai potensi desa wisata di suatu daerah bisa di sampaikan kepada calon wisatawan tanpa terhalang oleh faktor waktu dan tempat. Hal tersebut akan mengurangi kemungkinan wisatawan hanya mengetahui desa wisata tertentu saja. Dengan demikian, semua desa wisata dapat berlomba memberikan pelayanan terbaik untuk konsumen yang akan ditampilkan dengan bantuan teknologi tersebut. Lebih jauh lagi, pemerintah akan dapat memonitor desa wisata-desa wisata yang aktif dan potensial untuk dikembangkan. Bahkan, ketika pemerintah harus menyalurkan pendanaan ataupun mengadakan pelatihan untuk penguatan desa wisata, tidak akan salah sasaran disebabkan tersedianya sebuah basis data yang dapat diakses dengan mudah oleh siapa saja.

\section{LANDASAN TEORI}

\subsection{Pemanfaatan TIK pada sektor pariwisata}

Pemanfaatan TIK pada sektor pariwisata saat ini sudah menjadi sebuah kebutuhan dan menjadi salah satu komponen yang menentukan keberhasilan industri pariwisata di negara negara berkembang [2]. Melalui kombinasi yang sinergis antara sektor pariwisata dengan TIK akan memberikan dampak positif terhadap pertumbuhan dan perkembangan sektor pariwisata pada negara berkembang. Melalui internet, informasi mengenai keunikan, kelebihan, dan keindahan sebuah objek wisata diberbagai daerah bisa tersampaikan kepada calon wisatawan dengan cara yang mudah dan efisien. Internet sebagai salah satu produk dari TIK menjadi salah satu solusi yang yang bisa di andalkan untuk menyampaikan informasi mengenai potensi sebuah objek wisata kepada pihak yang membutuhkan yaitu calon wisatawan.

Salah bentuk strategi promosi yang bisa diwujudkan dengan memanfaatkan teknologi internet adalah menyediakan sebuah situs atau website yang memiliki informasi mengenai potensi potensi yang dimiliki oleh sebuah objek wisata. Dengan menyediakan sebuah website yang memiliki konten yang relevan dengan kebutuhan dari calon wisatawan, potensi potensi yang dimiliki dari sebuah objek wisata dapat tersampaikan dengan lebih tepat dan efisien. Hanya saja penggunaan $e$ commerce sebagai sarana promosi juga memiliki beberapa tantangan terkait bagaimana sebuah situs yang dibangun dapat memenuhi kebutuhan dari calon wisatawan. Dengan tersedianya sebuah situs yang mampu menyediakan layanan yang responsif dan variatif akan membantu calon wisatawan untuk memperoleh informasi dengan baik dan cepat yang tentu saja akan memberikan dampak yang positif terhadap sektor pariwisata [4]. Dengan tersedianya kolaborasi antara teknologi informasi dengan sektor pariwisata, dapat menjawab kebutuhan akan tersedianya interaksi antara sektor penyedia jasa wisata dengan calon wisatawan dan memberikan pengalaman baru mengenai pemerolehan informasi dan pengetahuan yang relevan bagi para calon wisatawan [5].

\subsection{Desa Wisata}

Desa wisata adalah sebuah wilayah pedesaan dengan keseluruhan suasana yang mencerminkan keaslian desa, baik dari struktur ruang, arsitektur bangunan, maupun pola kehidupan sosial-budaya masyarakatnya. Selain itu sebuah desa wisata mampu menyediakan komponen kebutuhan pokok wisatawan seperti akomodasi, makanan dan minuman, cinderamata, dan atraksi-atraksi wisata [6]. Dengan kata lain, desa wisata merupakan suatu bentuk integrasi antara atraksi, akomodasi dan fasilitas pendukung yang disajikan dalam suatu struktur kehidupan masyarakat yang menyatu dengan tata cara dan tradisi yang berlaku [7].

Terdapat dua buah komponen yang terdapat di dalam sebuah desa wisata. Komponen yang pertama adalah akomodasi, yang terdiri dari tempat tinggal penduduk setempat. Komponen yang kedua adalah atraksi, yaitu meliputi seluruh kehidupan penduduk sehari-hari dan kondisi fisik lokasi desa yang memungkinkan terjadinya interaksi antara wisatawan dengan penduduk dan lingkungannya. Sebagai contoh, para wisatawan dapat turut ambil bagian dalam menggembalakan sapi, memerah susu, mencari makanan untuk ternak, membatik, bahkan berkomunikasi dengan warga dengan bahasa seharihari penduduk di situ (bahasa daerah).

Pengembangan desa wisata dilandasi oleh paradigma community-based tourism[7]. Konsep pariwisata berbasis kerakyatan menekankan pada peningkatan peran serta masyarakat. Masyarakat setempat berkedudukan sebagai tuan rumah, sebagai 
pelaksana atau subjek dalam pengembangan pariwisata. Masyarakat juga yang akan menerima manfaat dari pengembangan pariwisata tersebut. Dengan demikian, keberadaan desa wisata akan menjamin keberlanjutan lingkungan, budaya, dan kultur yang dikelola, dimiliki, serta untuk kepentingan masyarakat itu sendiri [8].

\section{METODE PENELITIAN}

Untuk bisa menentukan interaksi yang tepat pada sebuah situs yang diharapkan dapat memenuhi kebutuhan dari calon wisatawan, perlu diterapkan sebuah metode analisa yang mengacu kepada kebutuhan pengguna dalam hal ini para wisatawan. Salah satu pendekatan yang digunakan dalam penelitian ini adalah dengan menggunakan pendekatan User Centerd Design (UCD). UserCentered Design adalah sebuah tahap pengembangan sebuah sistem yang menggunakan pendekatan terhadap pengguna dalam proses pengembangannya. Sehingga bagaimana nantinya sistem akan bekerja dan berinteraksi, semua didasarkan pada hasil analisa terhadap pegguna (wisatawan) yang akan menggunakan sistem ke depan. Tahapan dari pendekatan UCD dibagi kedalam beberapa tahapan di antaranya : Indentify needs and establish requirements, Design, Build an interactive version, dan evaluate [9].

Tahapan identify needs and establish requirements bertujuan untuk memahami pengguna dari sistem sebaik mungkin dengan mencoba menetapkan requirements berdasarkan kebutuhan dari pengguna. Dalam penelitian ini hasil dari requirements dimodelkan menggunakan diagram UML (Unified Modeling Language) dan ERD (Entity Relationship Diagram). Tahapan selanjutnya adalah membuat desain berdasarkan requirements yang sudah diperoleh pada tahap sebelumnya. Salah satu bentuk perwujudan dari desain yang dapat digunakan adalah prototype atau purwarupa. Pada penelitian ini, purwarupa diwujudkan dalam dua buah jenis purwarupa yang saling berhubungan. Kedua bentuk purwarupa tersebut adalah sebagai berikut: 1) Low-fidelity Prototyping adalah sebuah purwarupa yang menggunakan media yang berbeda dari produk akhir. Terkait dengan sistem yang akan dikembangkan, penggambaran dari desain sistem bisa di wujudkan dalam bentuk sketsa yang menjelaskan bagaimana sebuah sistem bekerja[10]. 2) High-fidelity prototyping adalah sebuah bentuk purwarupa yang menggunakan bahan yang serupa dengan produk akhir . Prototype jenis ini memiliki bentuk dan tampilan yang terlihat seperti produk akhir dari sebuah sistem. Hanya saja produk yang di hasilkan masih mengacu pada detail dari tampilan terkait alur kerja dari sistem[10].

Tahapan terakhir pada metode ini adalah evaluasi. Nantinya prototype yang sudah dibangun akan diujikan kepada pengguna untuk menguji seberapa tepatkah sasaran hasil analisa yang telah dilakukan pada tahapan sebelumnya. Dalam proses evaluasi ini, apabila ditemukan ketidaksesuaian antara rancangan sistem dengan kebutuhan dari pengguna, maka hasil rancangan bisa direvisi, dan menyebabkan tahapan dari UCD akan kembali ke tahapan sebelumnya. Tujuan dari tahapan ini adalah memungkinkan adanya penyempurnaan pada desain berdasarkan umpan balik dari pengguna.

\section{HASIL DAN PEMBAHASAN}

Tahapan pertama pada perancangan sistem basis data desa wisata ini adalah tahapan identify needs and establish requirements. Untuk bisa mendapatkan kebutuhan informasi yang tepat dan mampu mewadahi semua potensi dari desa wisata di Yogyakarta, maka peneliti melakukan pengumpulan data (data gathering) ke empat buah desa wisata yang tersebar di tiga buah kabupaten yaitu Sleman, Bantul dan Kulon progo. Desa wisata yang mewakili daerah Sleman adalah desa wisata Pentingsari. Desa wisata yang mewakili Kulon progo adalah desa wisata Kalibiru. Sedangkan desa wisata yang mewakili Bantul adalah Lopati dan Gilangharjo. Alasan dari pemilihan keempat desa wisata tersebut adalah keempat desa wisata tersebut memiliki prestasi dan keunikan keunikan yang bisa mewakili keragaman desa wisata yang terdapat di provinsi DIY.

Pada tahapan ini, terdapat beberapa metode yang dipergunakan untuk mengumpulkan data di antaranya wawancara kepada calon pengguna sistem baik pihak pemangku desa wisata maupun wisatawan desa wisata, serta melakukan kunjungan observasi ke empat desa wisata tersebut. Hasil dari observasi tersebut pada akhirnya digunakan sebagai dasar analisis pembangunan sistem basis data desa wisata. Dari hasil observasi dan analisis kepada keempat objek desa wisata tersebut, maka informasi potensi desa wisata bisa dibagi ke dalam beberapa kategori data sebagai berikut:

1. Profil Umum Desa Wisata

Kategori data ini berisi informasi mengenai informasi umum dari sebuah desa wisata meliputi nama, alamat, nomer kontak, alamat email, alamat sosial media, deskripsi umum dan foto dari desa wisata.

\section{Kondisi dan Potensi Geografis}

Kategori data ini berisi informasi mengenai potensi alam yang berada di desa wisata yang bisa menjadi daya tarik wisata bagi calon wisatawan. Data yang akan disimpan berupa nama potensi, deskripsi potensi dan foto potensi.

\section{Kuliner}

Kategori data ini berisi informasi mengenai potensi kuliner yang berada di desa wisata. Data yang akan disimpan berupa nama kuliner, deskripsi kuliner, foto dan jenis kategori dari kuliner seperti lauk pauk, jajanan pasar, makanan ringan dan minuman. 
4. Souvenir atau Kerajinan

Kategori data ini berisi informasi mengenai potensi souvenir atau kerajinan yang berada di desa wisata. Data yang akan disimpan berupa nama kerajinan, deskripsi kerajinan dan foto.

5. Aktraksi Wisata Pertunjukan

Kategori data ini berisi informasi mengenai potensi aktraksi wisata jenis pertunjukan. Beberapa contoh dari aktraksi wisata pertunjukan seperti pementasan ketoprak, pemtasan wayang, pemetasan jathilan dan berbagai aktraksi pertunjukan lainnya. Perbedaan aktraksi wisata jenis ini terletak pada keterlibatan wisatawan yang hanya sebagai penikmat atau penonton saja.

6. Aktraksi Wisata Aktifitas

Kategori data ini berisi informasi mengenai potensi aktraksi wisata jenis aktifitas yang memungkinkan adanya keterlibatan wisatawan. Beberapa contoh dari aktraksi wisata jenis aktifitas seperti permainan tradisional, melukis batik, melukis topeng maupun outbond.

7. Fasilitas Desa Wisata

Kategori data ini berisi informasi mengenai fasilitas yang dimiliki oleh sebuah desa wisata yang diharapkan bisa menambah daya tarik dari wisata. Beberapa contoh dari fasilitas desa wisata seperti tersedianya home stay, lapangan outbond, lapangan parkir dan lain sebagainya.

8. Biaya

Kategori data ini berisi informasi mengenai biaya yang ditetapkan oleh desa wisata untuk setiap paket wisata. Sebagai contoh adalah biaya untuk home stay, biaya untuk mengikuti paket aktraksi wisata dan lain sebaganua.

9. Kunjungan

Kategori ini berisi data kunjungan wisatawan yang bisa ditambahkan oleh masing masing desa wisata untuk menunjukkan eksistensi dari masing masing desa wisata tersebut. Data yang dicatat berupa nama grup wisatawan, asal, tanggal kedatangan, tanggal kepulangan, total peserta dan foto kegiatan.

10. Berita

Kategori ini berisi data berita terbaru yang bisa ditambahkan oleh masing masing desa wisata untuk menunjukkan eksistensi dari masing masing desa wisata tersebut.

11. Lain Lain

Kategori ini berisi informasi lain dari desa wisata yang berada diluar sepuluh kategori yang sudah dijabarkan di atas. Biasanya data jenis ini bersifat unik dan dimiliki oleh sebuah desa wisata saja.

Selanjutnya dari hasil analisis di atas dipergunakan untuk memodelkan rancangan basis data yang akan dipergunakan untuk menyimpan data oleh sistem menggunakan model entity relationship diagram (ERD ) seperti ditunjukkan pada Gambar 1.

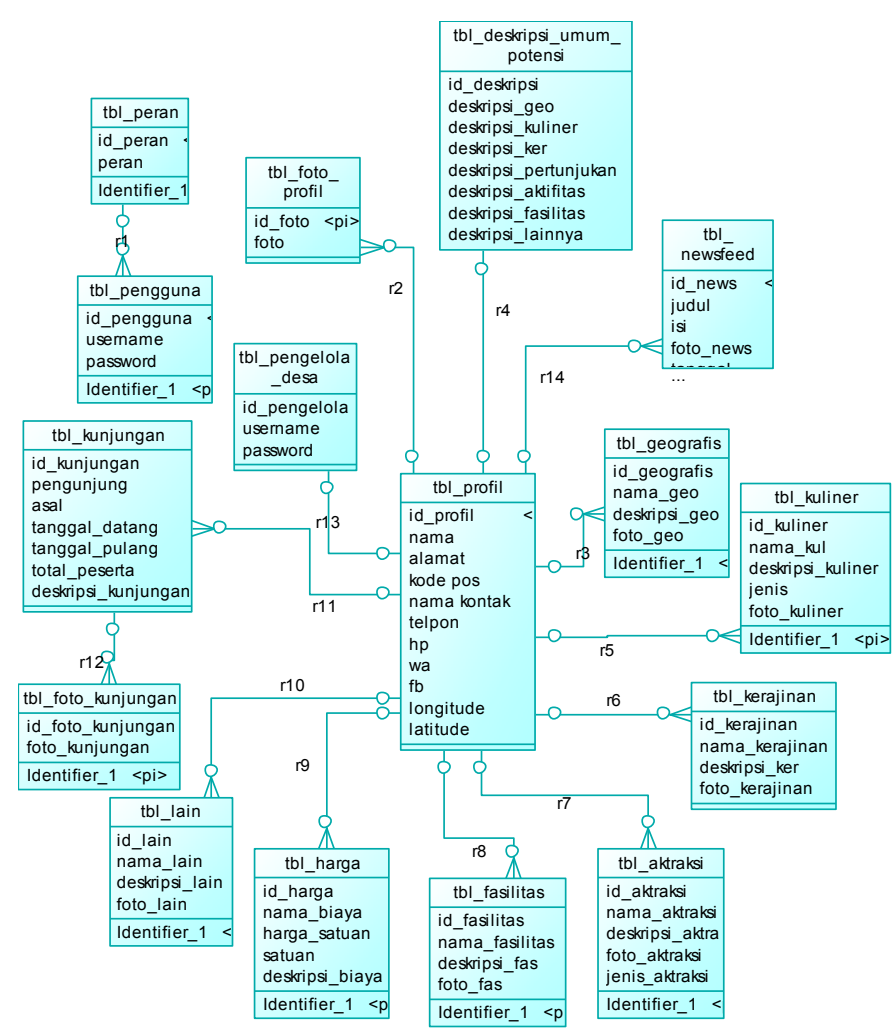

Gambar 1. ERD Sistem Basis Data Desa Wisata

Selanjutnya Aktifitas pada sistem basis data desa wisata ditunjukan melalui diagram use case pada Gambar 2. Terdapat tiga buah aktor pada aplikasi ini yaitu pihak administrator, pengelola desa wisata dan pengunjung web. Pada aplikasi web ini pihak administrator memiliki akses terhadap pengelolaan data utama (master) dari desa wisata seperti profil desa dan data potensi desa wisata yang meliputi data kuliner, kerajinan, aktraksi wisata, fasilitas, biaya dan data potensi lainnya. Selanjutnya untuk aktor pengelola desa wisata memiliki akses terhadap pengelolaan data kunjungan wisatawan dan data berita terbaru dari desa wisata tersebut. Sedangkan untuk aktor pengunjung web memiliki akses untuk melihat semua informasi mengenai profil, potensi potensi dan berita dari semua data desa wisata yang disimpan di sistem.

Setelah spesifikasi perancangan perangkat lunak dibuat menggunakan ERD dan UML, maka tahapan selanjutnya adalah membuat desain perancangan perangkat lunak. Pada tahapan ini akan dibuat sebuah Class diagram yang merupakan pemodelan dari kelas kelas yang nantinya akan diimplementasikan pada perangkat lunak. Class diagram pada dasarnya berisi method atau operasi dan relasi antar kelas. Class diagram tersusun atas tiga jenis kelas yaitu kelas boundary atau user interface (UI), kelas Control (ctrl) dan kelas entity. Gambar 3 menunjukkan class diagram dari sistem basis data desa wisata. 


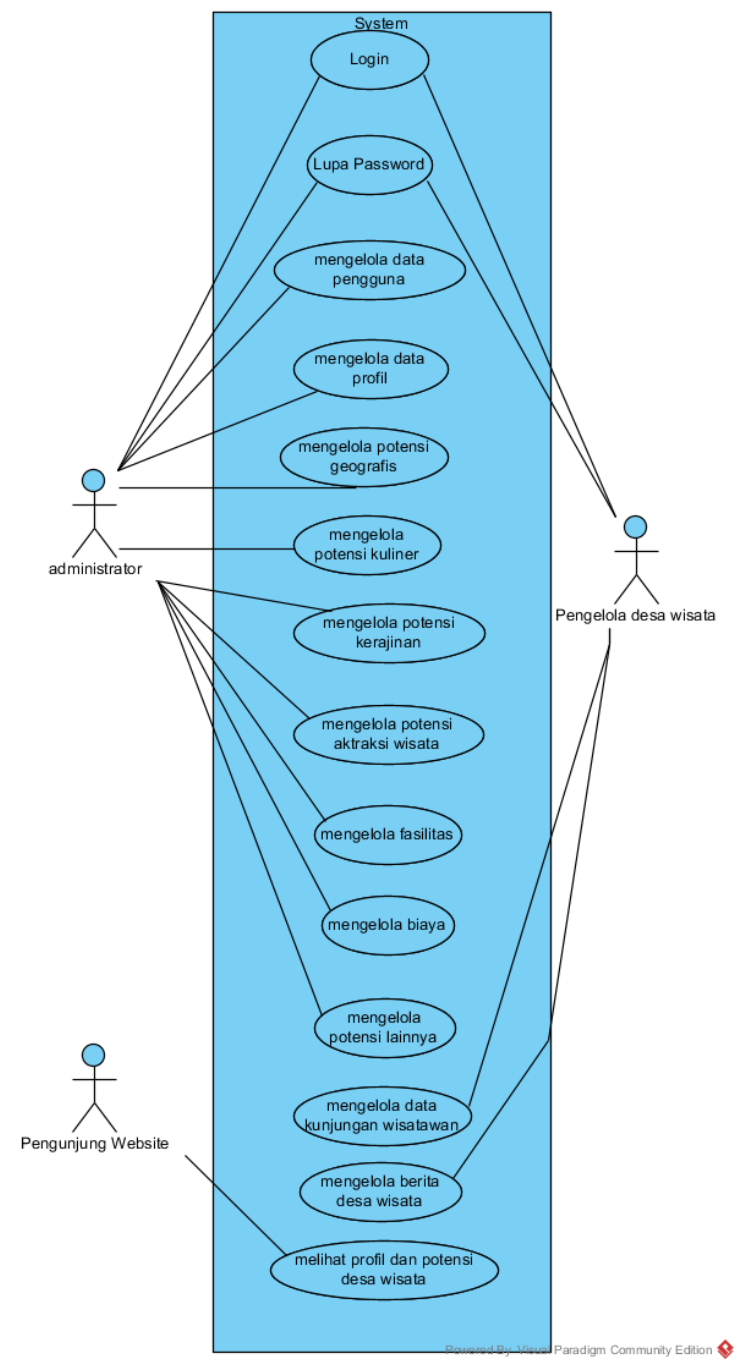

Gambar 2. Use case Sistem Basis Data Desa Wisata

Tahapan berikutnya pada perancangan sistem basis data desa wisata ini adalah pembangunan prototype atau purwarupa. Seperti telah dijelaskan sebelumnya, terdapat dua jenis purwarupa yang dibangun pada penelitian kali ini yaitu low fidelity dan high fidelity prototype. Rancangan dari purwarupa low fidelity adalah sebagai berikut:

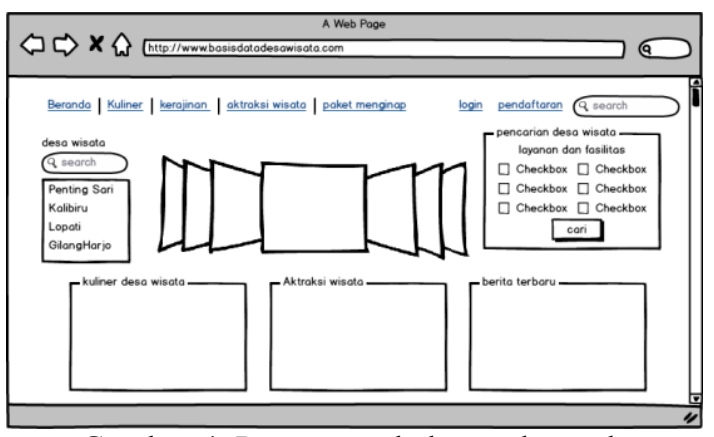

Gambar 4. Purwarupa halaman beranda

Purwarupa halaman beranda pada Gambar 4 berisi halaman utama dari web basis data desa wisata yang menampilkan rangkuman informasi dari semua desa wisata yang disimpan didalam sistem.

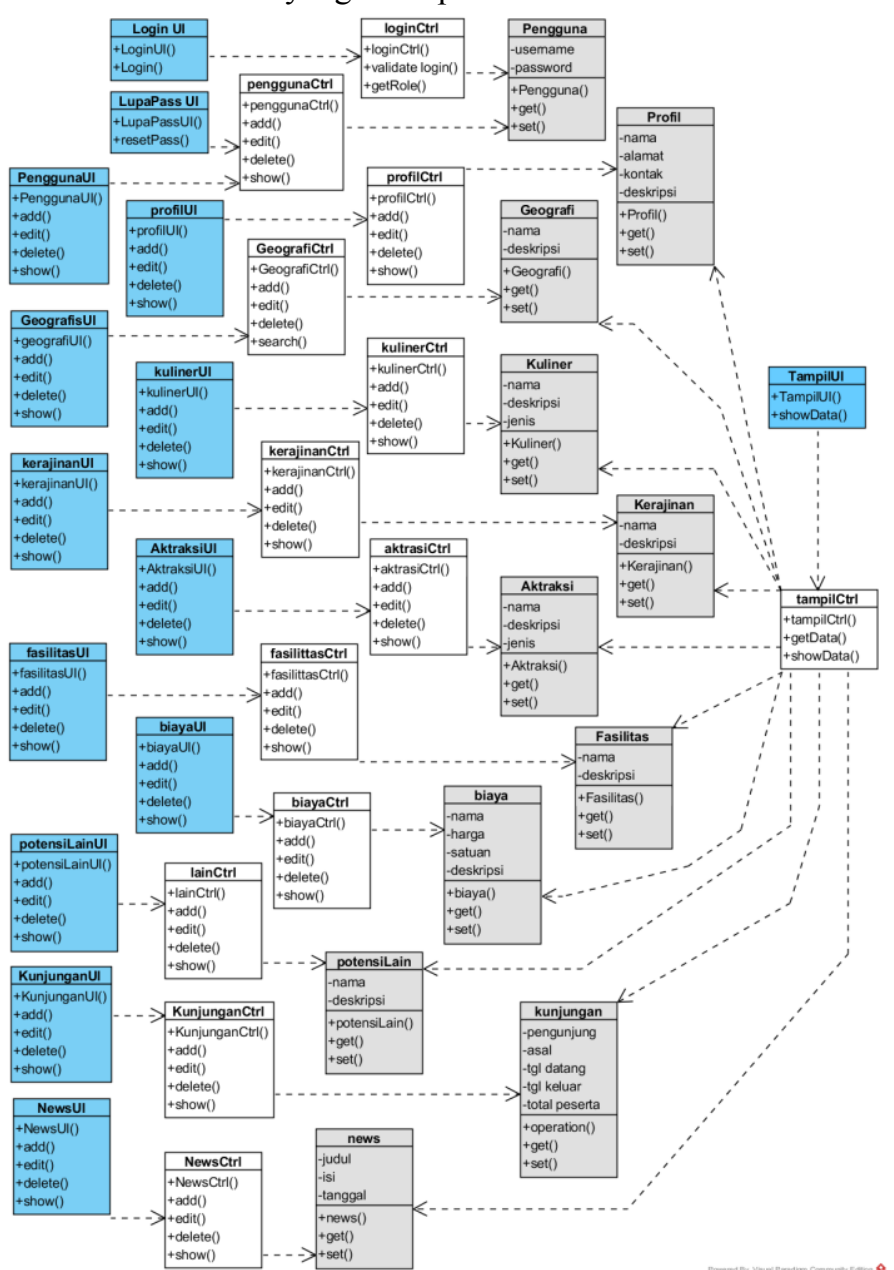

Gambar 3. Class Diagram dari sistem basis data desa wisata

Pada halaman web tersebut (halaman beranda), pengunjung bisa melihat daftar semua desa wisata yang ada di situs ini, dapat melakukan pencarian desa wisata berdasarkan layanan dan fasilitasnya, melihat berita terbaru dari desa wisata yang terkait dengan kunjungan wisatawan. Selain itu pengunjung juga bisa melihat informasi mengenai kuliner, kerajinan dan akstraksi wisata secara acak dari desa wisata di yogyakarta.

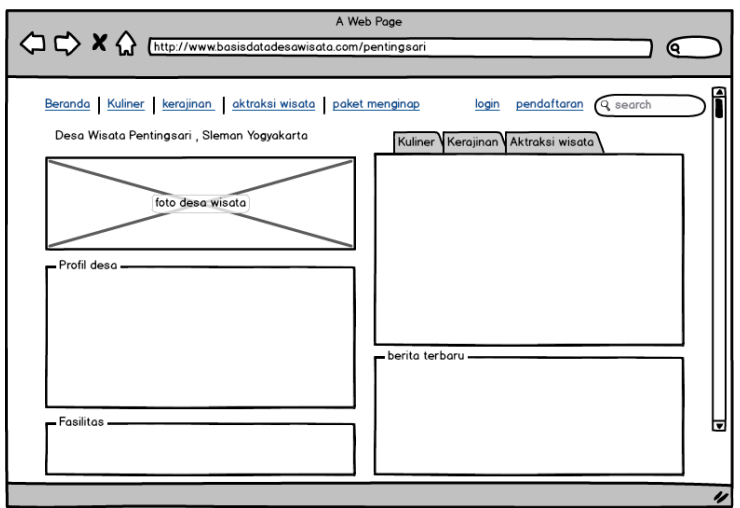

Gambar 5. Purwarupa halaman profil desa wisata 
Purwarupa pada Gambar 5 merupakan halaman web yang berisi profil tunggal dari desa wisata. Pada halaman web ini, pengunjung bisa melihat informasi dan potensi dengan detil dari desa wisata tersebut seperti potensi kuliner, kerajinan, akstraksi wisata dan lain sebagainya. Selanjutnya purwarupa pada Gambar 6 adalah Halaman web ini digunakan oleh pihak admin untuk mengelola data profil dan potensi dari desa wisata meliputi data profil, kuliner, kerajinan, aktraksi wisata, fasilitas, biaya dan lainnya. Gambar 7 adalah purwarupa dari Halaman yang dipergunakan oleh pihak pengelola desa wisata untuk mengelola data kunjungan dan data berita yang terkait dengan desa wisata yang mereka kelola. Sedangkan Gambar 8 adalah halaman yang dipergunakan oleh administrator untuk melakukan pengelolaan pengguna, termasuk didalamnya tambah pengguna baru, edit data pengguna lama, hapus, tampil dan cari data pengguna sistem.

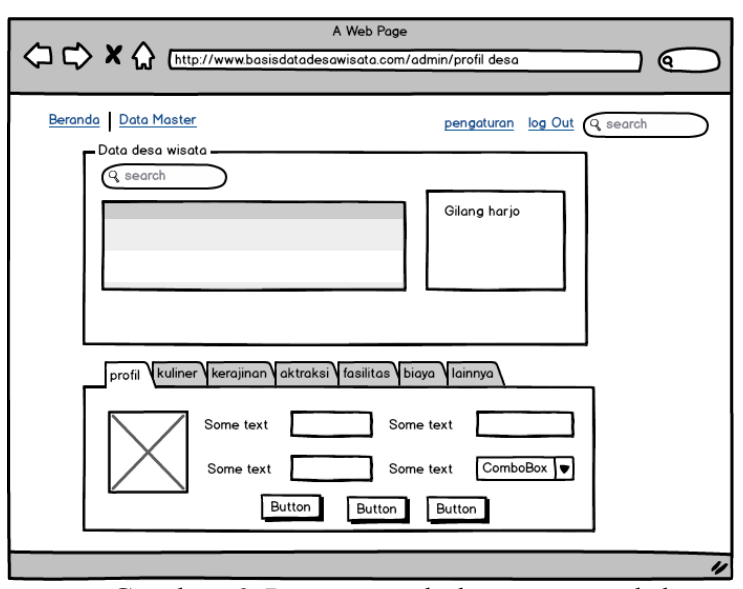

Gambar 6. Purwarupa halaman pengelolaan profil dan potensi desa wisata

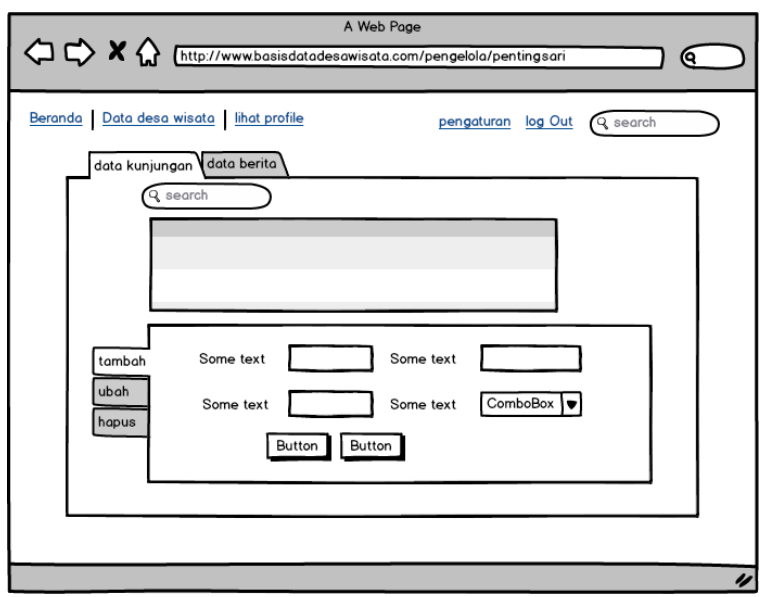

Gambar 7. Purwarupa halaman pengelolaan data berita dan kunjungan dari desa wisata

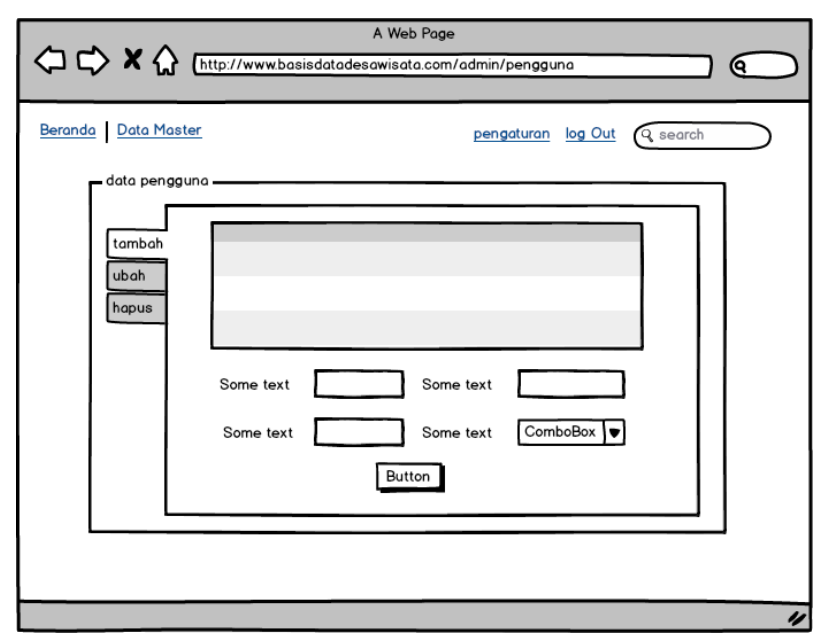

Gambar 8. Purwarupa halaman pengelolaan data pengguna

Selanjutnya tahapan terakhir dari perancangan sistem basis data desa wisata adalah membangun high fildelity prototype yang mengijinkan pengguna untuk berinteraksi dengan sistem walau masih dalam bentuk yang terbatas. Contoh rancangan high fidelity prototype dari sistem basis data desa wisata ditunjukkan pada Gambar 9, Gambar 10 dan Gambar 11.

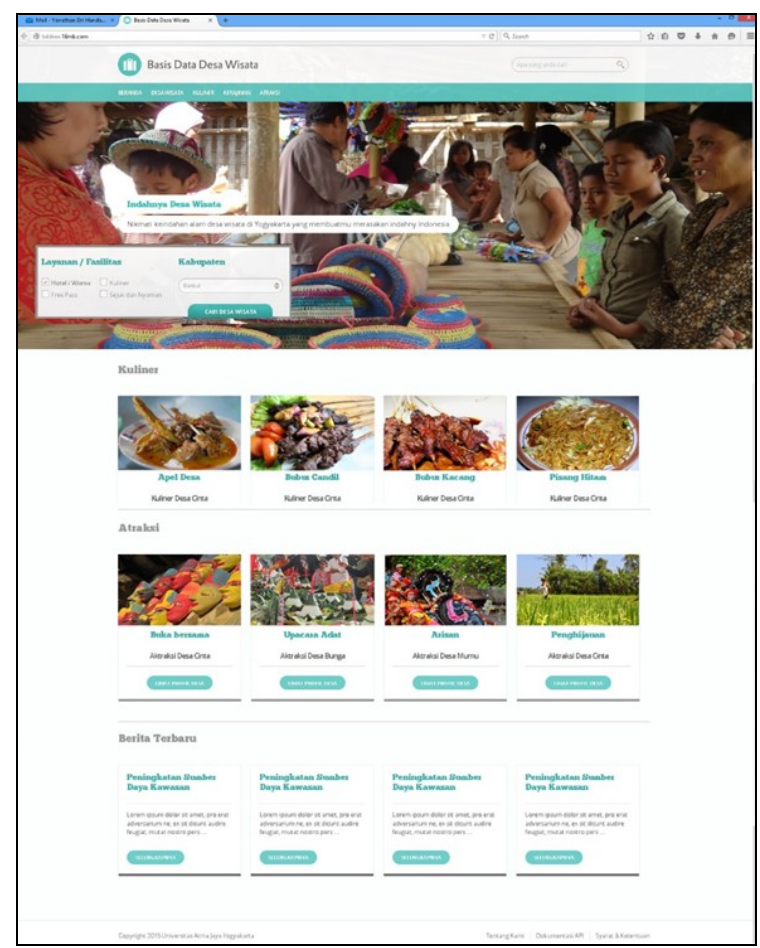

Gambar 9. High Fidelity prototype halaman beranda 


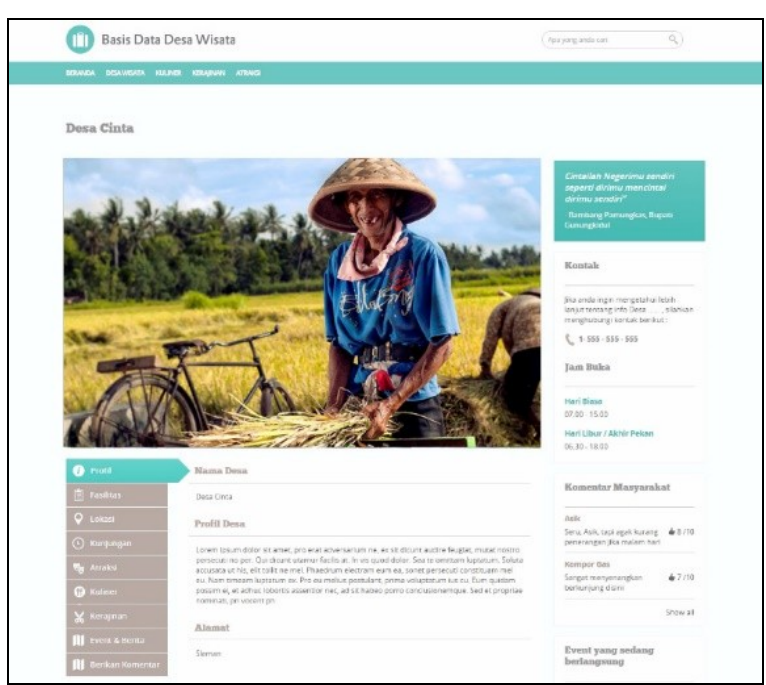

Gambar 10. High Fidelity prototype halaman profil desa wisata informasi umum

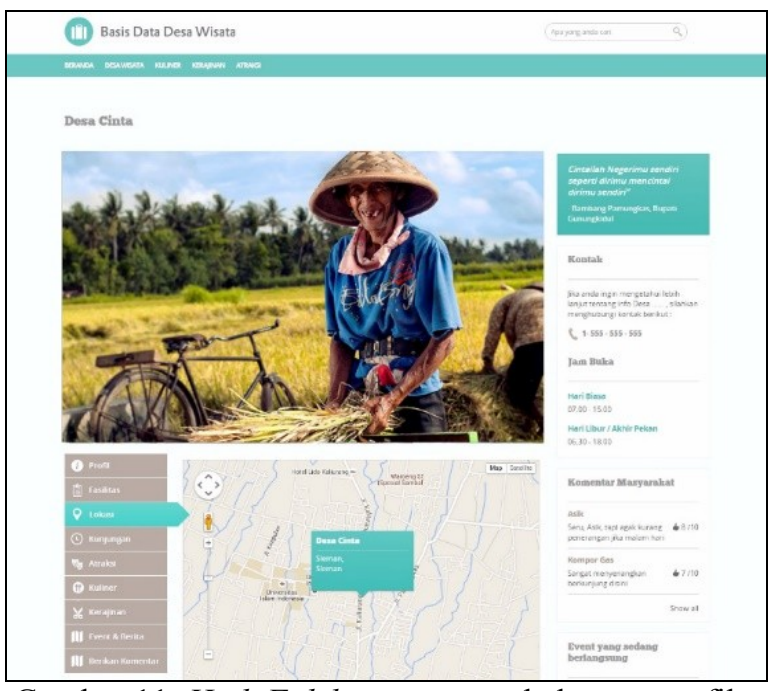

Gambar 11. High Fidelity prototype halaman profil desa wisata informasi peta

\section{KESIMPULAN}

Hasil akhir dari penelitian ini adalah menghasilkan sebuah sistem basis data desa wisata yang akan dipergunakan untuk menyimpan informasi profil dan potensi desa wisata yang berada di Yogyakarta. Diharapkan dengan dibangunnya sistem ini, akan membantu mempromosikan desa wisata yang terdapat di DIY dan membantu para calon wisatawan untuk memperoleh informasi yang lengkap mengenai desa wisata yang hendak dikunjungi. Dari sisi pemerintah, sistem basis data desa wisata ini dapat digunakan untuk memonitor desa wisata melalui indikator yang diberikan baik untuk kepentingan administrasi maupun pengembangan potensi pariwisata kedepannya.

Untuk kedepannya, dalam pengembangan sistem ini bisa menyediakan application programming interface (API) agar sistem ini kedepannya bisa diperluas agar bisa diakses oleh aplikasi berbasis mobile sehingga sistem ini bisa diakses oleh wisatawan melalui perangkat mobile.
Selain itu dengan tersedianya API dari sistem ini akan berpeluang membuka kerja sama dengan banyak pihak untuk turut serta mempromosikan desa wisata di Yogyakarta dengan memanfaatkan TIK.

\section{REFERENSI}

[1] Bethapudi, Anand.2013.The Role of ICT in Tourism Industry. Journal Of Applied Economics And Business, Vol.1, Issue 4 December, 2013, Pp. 67-79.

[2] Ali, Vizaad;Cullen, Rowena;Toland, Janet. 2013.Information and Communications Technology in the Tourism Sector of the Maldives: an Institutional Perspective. 46th Hawaii International Conference on System Sciences

[3] Shafiee, M.M.;Shams, H. ; Yahai, M.R. ; Golchin, H.2013. ICT capacities in creating sustainable urban tourism and its effects on resident quality of life. E-Commerce in Developing Countries: With Focus on eSecurity (ECDC), 2013 7th Intenational Conference on

[4] Fang, Min.2011.'Innovation pattern of China tourism e-commerce on the post-crisis era". This paper appears in: Artificial Intelligence, Management Science and Electronic Commerce (AIMSEC), 2011 2nd International Conference on

[5] Xiaoying, Li. 2012. "Innovation of Tourism Information Services based on Internet Technology". Fuzzy Systems and Knowledge Discovery (FSKD), 2012 9th International Conference on.

[6] Permanasari, Ika Kusuma. 2011. Pemberdayaan Masyarakat Melalui Desa Wisata Dalam Usaha Peningkatan Kesejahteraan. Tesis Program Magister Perencanaan dan Kebijakan Publik, Univeritas Indonesia.

[7] Permanasari, Ika Kusuma. 2006. Pengembangan Desa Wisata dalam Konteks Berbasis Kerakyatan dan Berkelanjutan. Jurnal Kepariwisataan Indonesia, Volume 1, No. 2, Juni 2006.

[8] Goodwin, Harold \& Santilli,Rosa . 2009. Community-Based Tourism: A Success? ICRT Occasional Paper 11.

[9] Preece, Jenny; Sharp, Helen; Rogers, Yvonne. 2015.Interaction Design: Beyond HumanComputer Interaction, 4th Edition. John Wiley \& Sons Ltd.

[10] Blacker, Alethea. 2009. Applications of high and low fidelity prototypes in researching intuitive interaction. Design Research Society Conference 2008, Sheffield Hallam University, Sheffield, UK. 